\title{
Historia literatury polskiej dla XXI wieku
}

Andrzej Skrendo

TEKSTY DRUGIE 2019, NR 4, S. 138-151

DOI: 10.18318/td.2019.4.8 | ORCID: 0000-0002-7402-2048

1.

Historia literatury polskiej Anny Nasiłowskiej jest dziełem wyjątkowym ${ }^{1}$. Pierwszym od dawna opracowaniem dziejów całej literatury narodowej napisanym przez jednego autora - i do tego w jednym, obszernym, tomie. Najbliższy kontekst tworzą dla tej opowieści The History of Polish Literature Czesława Miłosza (1969; polskie wydanie 1993, 2010), Dzieje literatury polskiej Juliana Krzyżanowskiego (1969; Historia literatury polskiej od początku do rozbiorów, 1939), Juliusza Kleinera Zarys dziejów literatury polskiej (t. 1. 1932, t. 2. 1939; uzupełniony o okres od 1918-1966 przez Włodzimierza Maciąga, 1972), a także Manfreda Kridla Literatura polska. (Na tle rozwoju kultury) (1945; w wersji przetłumaczonej i przerobionej z autorem przez Olgę Scherer-Virski, A Survey of Polish Literature and Culture, 1956). Ale nawet sięgając dalej w przeszłość nie

\section{Andrzej Skrendo - historyk i teoretyk literatury. Ostatnio opracował „Wybór poezji"Tadeusza Ró- żewicza w Bibliotece Narodowej (2017). Pracuje na Uniwersy- tecie Szczecińskim.}

1 A. Nasiłowska Historia literatury polskiej, Wydawnictwo IBL PAN, Warszawa 2019. Dalsze odwołania lokalizuję w tekście głównym. 
znajdziemy tego rodzaju prób wiele. Zatem - zacznijmy od tak zarysowanego kontekstu ${ }^{2}$.

Kleiner pragnął dać, jak wykładał we wstępie, coś więcej niż wynikało z tytułu: „jednolitą opowieść o kulturze narodowej”’ Odróżnić „wartości trwałe”, od tych, „które należało i należy w narodzie tępić”. Pragnął być „przewodnikiem”, który ukaże „żywą jedność” i „uderzy przy tym w ton odpowiedni dla młodzieży”. Ufał, że czytelnicy doznają dzięki niemu „wzbogacenia duszy” oraz „rozradowania, którym darzy obcowanie ze sztuką i z przeszłością”. A wszystko to „w dzisiejszych czasach utylitaryzmu skrajnego".

W podobnym tonie pisał Kleiner o Wartościach światowych literatury polskiej (1938), ale tu już wypowiedział słowa znaczące: „Literatura francuska większa jest niżli Corneille, Racine i Molière. Mickiewicz natomiast - jest większy niż literatura polska"4. Jeśli się chwilę zastanowić - jest to surowe zdanie. Trochę przypomina opinię Gombrowicza wypowiedzianą w Dziennikach: że w literaturze polskiej są same arcydzieła, nie ma tylko literatury. Kleiner zresztą, choć zachwycony "poetami-prorokami skazanego na śmierć narodu"s , ostatecznie nie bardzo potrafił wyjaśnić, na czym polega wyjątkowość naszej literatury. Zamiast tego usiłował odpowiedzieć na pytanie, czemu ta wyjątkowość nie jest oczywista ani na Wschodzie, ani na Zachodzie. Pewien był jednego - że opowieść o literaturze to najlepsza forma wyrażenia istoty narodu, czyli za pewnik przyjmował, iż literatura znajduje się w centrum kultury.

Julian Krzyżanowski z dystansem odnosi się do tezy mówiącej o wyjątkowości literatury polskiej w skali Europy i świata, a z jawną ironią do przeświadczenia, że pozycje tę zawdzięcza swej głównej cesze, którą jest umiłowanie ojczyzny - jako rzecznik tej tezy występuje Ignacy Chrzanowski (ale przecież nie tylko o niego chodziło). Powiada, że w sądach takich jest za dużo patosu i „szlachetnej egzaltacji”, a tymczasem sprawa wydaje się

2 Inny kontekst tworzą wcześniejsze prace Nasiłowskiej: Trzydziestolecie 1914-1944 (Wydawnictwo Naukowe PWN, Warszawa 1995) oraz Literatura okresu przejściowego 1976-1996 (Wydawnictwo Naukowe PWN, Warszawa 2007), a także Literatura współczesna. Podręcznik dla szkół ponadpodstawowych (Stentor, Warszawa 1997).

3 Zarys dziejów literatury polskiej. Część I i II napisał J. Kleiner, cz. III napisał W. Maciąg. Ossolineum, Wrocław-Warszawa 1974, s. 9-11.

4 Wartości światowe literatury polskiej, w: tegoż W kręgu historii i teorii literatury, wybór i oprac. A. Hutnikiewicz, Wydawnictwo Naukowe PWN, Warszawa 1981, s. 38.

5 Tamże, s. 36.

6 J. Krzyżanowski Dzieje literatury polskiej, Wydawnictwo Naukowe PWN, Warszawa 1972, s. 647. 
„wysoce zawiła i nie do przyjęcia w postaci, którą się zazwyczaj spotyka”. Ostatecznie Krzyżanowski kończy jednak na przeformułowaniu, co sam przyznaje, poglądu Chrzanowskiego - z tą korektą, że zamiast o patriotyzmie woli mówić o życiu zbiorowym, które w naszej literaturze bierze górę nad życiem indywiduum. Zapewnia, że z tego powodu literatura polska okazuje się „literaturą przyszłości" - ale właściwie nie wiadomo, skąd ten wniosek się bierze.

Czesław Miłosz we wstępie (skierowanym, jak cała książka, do czytelnika posługującego się językiem angielskim) zgadza się, że literatura polska „może zawierać pewną lekcję o uniwersalnym znaczeniu”, ale z powodu wielce osobliwego: bo sprawia wrażenie „chaosu pozornie tak niewspółmiernych, a przecież powiązanych ze sobą jakąś logiką elementów" ${ }^{8}$. Miłosz podważa „banały stosunkowo świeżej daty”, że istotą literatury (i kultury) polskiej są romantyzm, rzymski katolicyzm oraz dziedzictwo kontrreformacji. Podkreśla za to obecność „dziedzictwa intelektualnej buntowniczości”, które nigdy nie zostało zatracone, a które polega na liberalizmie, antyklerykalizmie oraz „skrajnym sceptycyzmie co do jakichkolwiek dogmatów (czy to religijnych czy politycznych)"

W takim kontekście dla zrozumienia książki Anny Nasiłowskiej najważniejsze okazuje się pytanie wypowiedziane przez autorkę na samym końcu: „Czy kultura polska jest jeszcze «literaturocentryczna»?" (s. 655). Odpowiedź, którą przynosi cała książka, brzmi, jak się zdaje, następująco: w szybko malejącym stopniu, w małym stopniu lub wręcz w stopniu nikłym. Podaję tu trzy odpowiedzi, które są w zasadzie identyczne - różnią się jedynie kategorycznością. Ale w sytuacji w jakiej się znajdujemy, owa różnica kategoryczności ma wielkie znaczenie. Zauważmy jednak od razu - literatura i historia literatury w kulturze nieliteraturocentrycznej mogą istnieć i istnieją; mimo, że dla wielu z nas owo życie może wydawać się życiem pośmiertnym. Być może to kwestia pokoleniowa, a być może koniec czegoś, co dla historyków literatury polskiej od zawsze (czyli mniej więcej od XIX wieku) do dziś było oczywistością, która nadawała sens ich pracy. Na pewno nadawał sens pracy Kleinera, równie mocno - choć w nieco innym sensie - Krzyżanowskiego. Inna była sytuacja Miłosza - z tego powodu, że wydał swą książkę po angielsku i zwracał się do czytelnika obcojęzycznego. Czyniąc prymarnym językiem

7

Tamże, s. 648 .

8 Cz. Miłosz Historia literatury polskiej, przeł. M. Tarnowska, Kraków 2010, s. 13. 
wykładu angielszczyznę (Miłosz swą książkę dyktował po angielsku) umieszczał wywód w odmiennej niż w Polsce konfiguracji społecznej i kulturowej.

Sytuacja Nasiłowskiej najbardziej przypomina sytuację Miłosza. Stwierdza ona, że "nieznajomość języka polskiego nie jest przeszkodą uniemożliwiającą korzystanie z tej książki" (s. 10), i dodaje, że adresuje swe dzieło do czytelnika, który o polskiej literaturze „niewiele wie” (s.9). Wynika z tego, jak się zdaje, że wiedza czytelnika polskiego o literaturze polskiej nie różni się mocno od wiedzy czytelnika obcego. Wolno by oczywiście pomyśleć, że Nasiłowska po prostu pragnie trafić do jak najszerszego grona odbiorców - ale przecież nie ma powodów by sądzić, że nie zależało na tym autorom poprzednich syntez. Ostatecznie zatem rzecz sprowadza się do tego, jak wyobrażamy sobie owego reprezentanta szerokiego grona odbiorców. I właśnie w tym wyobrażeniu zaszła zmiana, którą sygnalizuje zadane przez Nasiłowską na końcu książki pytanie. Czytelnikiem modelowym staje się ktoś, kto „niewiele wie". Albo inaczej: w sytuacji przeżywanej przez nas przemiany modelu czytelnictwa lektura tak zwanej literatury pięknej chyba w każdym możliwym sensie przestaje być doświadczeniem wzorcowym. Odtąd inaczej jawi się również rola przewodnika, na którą taki nacisk kładł Kleiner - ale przecież rola ta nie znika.

Nasiłowska, jak jej poprzednicy, zadaje też sobie pytanie, czy „Czy literatura polska jest wyjątkowa?”. Trochę jak Krzyżanowski odpowiada, że sprawa jest,,jednak dość skomplikowana” (s. 249). Dodaje, że ta wyjątkowość nie wynika z porównania z innymi literaturami, ale z przekonania o niezwykłej roli literatury polskiej w życiu narodu pozbawionego państwa. Kleiner w przywoływanym artykule (dość niejasno) wykładał, że wprawdzie, zwłaszcza w naszym romantyzmie, „nieskończenie wysoko wznoszą się pierwiastki ludzkie i pierwiastki boskie”, ale nie osiągają jednak „typowości ogólnoludzkiej”"10. Krzyżanowski poprzestawał na zapewnieniu, „że i Kasprowicz, i Miciński, i Wyspiański zasługują na to, by wejść do panteonu największych pisarzy naszego stulecia"11. Nasiłowska jak Miłosz (choć powołuje się na Marię Janion) uznaje, że „Jeśli nawet romantyzm odpowiedzialny jest za wyjątkowość, to warunkiem «normalności» byłoby jego odrzucenie, a przynajmniej odrzucenie mesjanizmu" (s. 249). To przeciwstawienie wydaje się symptomatyczne - Nasiłowska jako historyk literatury pragnie „normalności”, ale

10 Kleiner Wartości..., s. 39.

11 Krzyżanowski Dzieje literatury polskiej, s. 652. 
w cudzysłowie, bo wie, że właśnie to pragnienie było dotąd czymś nienormalnym. Nie pragnie zaś wyjątkowości.

W tym kontekście znaczące wydaje się, że gdy przedstawia swą ideę polskości powołuje się na pisarza, było nie było, angielskiego - Josepha Conrada. Cytuje fragment wstępu do A Personal Record: „Tak zwany w literackim świecie «słowiański duch» jest absolutnie obcy polskiemu temperamentowi z jego tradycją wolności, jego rycerskim poglądem na moralne wędzidła i przesadnym szacunkiem dla praw jednostki; pominąwszy już ten ważny fakt, że polska umysłowość, zachodnia z natury, kształtowała się na wzorach włoskich oraz francuskich, sympatyzując zawsze, jak świadczy historia, nawet w sprawach religijnych, z najbardziej liberalnymi prądami myśli europejskiej". We fragmencie tym zawarta jest jednak niepokojąca opozycja, nad którą Nasiłowska przechodzi do porządku dziennego: przecież ów „słowiański duch”, to duch rosyjski, duch przemocy i zniewolenia, zatem Conradem powoduje raczej obca „liberalnym prądom myśli europejskiej” obsesja antyrosyjska. Wiemy, jak była silna - i jaki miała wpływa na jego pisarstwo. Wspominam o tym, gdyż to fakt znaczący: również u Conrada odkrywamy jakiś rodzaj niejawnego uwikłania w problematykę specyficznie polską, która nie musi być jasna dla kogoś z zewnątrz.

\section{2.}

„Na początku XXI wieku praktykę naukową nadal determinuje zorientowany narodowo model pisania historii literatury - choć w mniejszym stopniu chodzi o opis «ducha narodu», a w zdecydowanie większym o ukazanie i refleksję nad tożsamością kulturową społeczeństwa. Prace historycznoliterackie pełnią funkcję społeczno-kulturową w instytucjonalnie zorganizowanej praktyce zapamiętywania i zapominania, w pojmowaniu tradycji. W przeważającej części dzisiejsze historie literatury nie są «wielkimi narracjami» (takimi jak księga Genesis w Starym Testamencie czy Iliada Homera), ale wydają się ważnym wkładem w «(zbiorową) pamięć kulturową» społeczeństwa" - pisze Jörg Schönert w obszernym haśle Literaturgeschichtsschreibung zawartym w trzytomowym słowniku literaturoznawstwa pod redakcją Thomasa Anza ${ }^{12}$. Książka Anny Nasiłowskiej jest historią literatury dla XXI wieku również w takim sensie, o jakim mówi Schönert. Przedstawia zręby czegoś,

12 Handbuch Literaturwissenschaft. Gegenstände - Konzepte - Institutionen. Sonderausgabe, hrsg. von T. Anz, t. 2, Verlag J. B. Metzler Stuttgart-Weimar 2013, s. 269. 
co nazywa imaginarium polskim - i przyjmuje to za swój cel strategiczny. Widać to dobrze w rozdziale poświęconym literaturze średniowiecznej, która nie jest opisywana z punktu widzenia swej wartości literackiej, ale właśnie jako najstarszy i trwały zasób polskich wyobrażeń symbolicznych. Strategia ta słabnie w miarę zbliżania się do czasów współczesnych, a raczej - nie tyle słabnie, ile traci swą widoczność, choć działa wciąż równie mocno. Od czasów najdawniejszych wychodzą bowiem swego rodzaju linie ciągłości, które biegną do dziś i tną w poprzek podział na epoki, a zarazem mają spory udział w ustanawianiu względnej autonomii tychże epok. Tak chyba należy tłumaczyć autorski pomysł na kompozycję tomu: w tej liczącej około 660 stron pracy, w czasach romantyzmu, a więc w szeroko rozumianej nowoczesności, znajdujemy się już od mniej więcej 160 strony! Po zarysowaniu imaginarium, uznając okres staropolski (oświecenie to swego rodzaju miejsce graniczne) za czas jego narodzin, Nasiłowska większość swych sił - na przestrzeni pozostałych 500 stron - poświęca dociekaniom na temat tego, jak owo imaginarium (niejawnie) działa.

Nasiłowska usiłuje ponadto wpłynąć na proces kulturowego pamiętania i zapominania modeli polskiej tożsamości. Nie sposób wdawać się tu w obszerne objaśnienia, zatem tylko dwie hipotezy dotyczące tego, jak można by rozumieć (niejawny) teoretyczny kontekst narracji przez nią podjętej. Pierwszą podsuwa Schönert, który odwołuje się do pojęcia pamięci kulturowej Jana Assmana ${ }^{13}$.W języku Assmana można by powiedzieć, że Nasiłowska opisuje literacki aspekt struktury konektywnej polskiego społeczeństwa - przedstawia to, co najczęściej powtarzano, ale też to, co sama uważa za godne powtarzania. W związku z tym, że dziś koherencja ma charakter (jeszcze?) tekstualny, pamięć przechowuje się dzięki wysiłkowi rozumienia, czyli za pomocą hermeneutyki. Jak jednak wiemy - przed laty sugestywnie pisał o tym w „Tekstach" Janusz Sławiński - hermeneutyka pozostaje w rażącym konflikcie z historią literatury, od pojedynczego dzieła nie ma bowiem przejścia ani do procesu, ani do systemu (narracja i encyklopedia to dwie skrajne wizje pisania historii literatury), lecz jedynie przeskok. Sławiński powiada, że trzeba by więc pomyśleć historię taką, która byłaby „dyscypliną wolną od neurotycznego lęku przed posądzeniem o to, że stanowi nadbudowę nad konwencjami lekturowymi publiczności, bez wstydu potwierdzająca, że tak

13 Poprzez pracę Kollektives Gedächtnis und kulturelle Identität zawartą w tomie Kultur und Gedächtnis pod red. samego Assmana oraz T. Hölschera, Frankfurt a. M. 1988. Zawiera ona zwięzły opis pamięci komunikacyjnej i kulturowej jako dwóch form pamięci zbiorowej. 
się właśnie rzeczy mają. Działająca z pełną świadomością, że stosowane przez nią narzędzia analizy, interpretacji i wartościowania dzieł są zakorzenione w historycznie i środowiskowo zdeterminowanych technikach czytania".Tak czyni Nasiłowska, często powołując się na swoją (naszą) teraźniejszość jako uprawomocnienie dokonywanych wyborów i ocen. Czy tak pojęta historia nie jest już jednak raczej pamięcią? ${ }^{14}$

Ale Nasiłowska robi coś jeszcze - ważną częścią jej metody staje się swego rodzaju sproblematyzowane streszczenie. Wybór tej formy wynika, rzecz jasna, z zakładanej wizji czytelnika, ale nie tylko. To właśnie sproblematyzowane streszczenie wypełnia przepaść między hermeneutyką a historią częściowo zastępuje, a częściowo prowadzi do interpretacji (różnie w różnych przypadkach). A ponadto - to przecież streszczenie ujmuje to, co należy powtarzać. I jeszcze więcej - odsuwa lub jakby zluzowuje kłopotliwą kwestię samego statusu tekstu literackiego oraz arcydzielności we współczesnej świadomości kulturowej. Nasiłowska zresztą chętnie, gdy może, odwołuje się do innych mediów, zwłaszcza do filmu.

Druga z hipotez pochodzi od Andreasaa Huyssena jako autora Twilight Memories. Powiada on, że współczesna obsesja na punkcie pamięci wynika z działania wirusa amnezji, który rozprzestrzenia się poprzez nowe media. Przejście od historii do pamięci stanowi pożądaną krytykę skompromitowanych ujęć teleologicznych, nie jest zaś jedynie przejawem relatywizmu. Wyraża nasze pragnienie „zakotwiczenia w czasie”, 15 "podstawową ludzką

Można by powiedzieć, że Nasiłowska daje nam nie historię, lecz wizję ustrukturowania naszej pamięci kulturowej przez literaturę. To, co pisze, zbyt mocno jest bowiem odniesione do jej własnego postanowienia dotyczącego tego, czym literatura polska jest, a znajduje niepewne oparcie - nie z własnej winy - w szerszych ramach, by tak rzec, epistemologicznej lub scjentystycznej intersubiektywności. Assman pisał: „Istnieje bowiem wiele pamięci zbiorowych, lecz tylko jedna historia, która wyzbyła się wszelkiego odniesienia do pojedynczej zbiorowości, tożsamości czy punktu widzenia i która rekonstruuje przeszłość w przestrzeni całkowicie abstrakcyjnej tożsamości, gdzie wszystko odnoszone jest, jak mówi Ranke, «bezpośrednio do Boga», bo «niezależne od osądu grupy», która zawsze odnosi osąd do samej siebie i pozostaje stronnicza" (J. Assman Pamięć kulturowa. Pismo, zapamiętywanie i polityczna tożsamość w cywilizacjach starożytnych, przeł. A. Kryczyńska-Pham, wstęp i red. naukowa R. Traba, Warszawa 2005 , s. 59). Nasiłowska bierze zatem udział w konflikcie różnych pamięci, interesy swoje i swojej grupy przeciwstawia interesom innych grup społecznych - a grunt, na którym stoi, śmiało ujawnia. Poprzez, między innymi, odwołanie do Conrada - co oznacza, że kultura polska w swym wnętrzu nosi obcość. Tak samo jak angielska - i każda inna.

15 A. Huyssen Twilight Memories: Marking Time in a Culture of Amnesia, Routledge, New York and London 1995, s. 7 . 
potrzebę życia w szerszych strukturach czasowości"16. Historia zatem słabnie. Rozwój technologiczny niszczy samo poczucie historyczności, a nasze nadzieje skierowane w przyszłość i ożywiane obietnicami składanymi przez technologię okazują się paradoksalne, ponieważ zapowiadana przyszłość zatrze (już zaciera) odróżnienie teraźniejszości, przeszłości i przyszłości. Huyssen bardzo czuły jest na ambiwalencję pamięci. Nazywa ją potentially healthy sign of contestation: a contestation of the informational hyperspace, a więc tylko (i aż) „potencjalnie zdrowym znakiem kontestacji”" Potencjalnie, bo istnieje zagrożenie, że w przyszłości przeszłość będzie już tylko pamięcią: czyli retroaktywnie ustanawianą hipostazą teraźniejszości. Pamięć kulturowa, funkcjonująca w warunkach silnych konfliktów kulturowych, a zatem gdy kanały komunikacji społecznej przekazują obrazy wzajem się wykluczające i niewspółmierne, rozpada się - niejako z powodu własnego nadmiaru. Co więcej, arbitralnie wyklucza - poprzez zapomnienie, którym da się politycznie kierować. Tymczasem chcielibyśmy wierzyć - i wierzy w to Nasiłowska - że choć posiadamy różne opowieści o historii literatury, samą literaturę mamy jedną. ${ }^{18}$

16 Tamże, s. 9.

17 Tamże.

18 Assman przedstawia pamięć jako swego rodzaju farmakon: istnieje alians władzy i zapominania, który najlepiej przedstawił Orwell, a zarazem pamięć może stać się, w warunkach ucisku, formą oporu (Pamięć kulturowa... s. 87). Jacques Le Goff przestrzega: „Istnieją co najmniej dwie historie [...] historia pamięci zbiorowej i historia historyków. [...] Historia powinna rozjaśniać pamięć i pomagać w prostowaniu jej omyłek" (J. Le Goff Historia i pamięć, przeł. A. Gronowska, J. Stryjczyk, wstęp P. Rodak, Warszawa 2007, s. 171). Andrew Hoskins dowodzi, że "usieciowione jaźń i społeczeństwo sprawiają, że przeszłość i teraźniejszość zapadają się w orgię hiperkonektywności" (The Restless Past. An Introduction to Digital Memory and Media, w: Digital Memory Studies: Media Pasts in Transition, ed. A. Hoskins, Routledge 2017, s. 2), "przeszłość została pozbawiona retrospektywnej spójności i stabilności, uwikłana w dzisiejszą bijatykę niepewności" (tamże, s. 6), pilnie potrzebujemy zatem czegoś, co Hoskins nazywa new memory ecology. Opisuje ona, jak media oddziałują na ludzką percepcję, rozumienie, emocje i wartości oraz w jaki sposób nasza interakcja z mediami ułatwia lub ogranicza nasze szanse na przetrwanie (jest to ekologia, bo to media są naszym środowiskiem). Mniejsze zaufanie ma do owej ekologii Dawid Lowenthal, który zauważa, że obecnie "historia nie jest już uprzywilejowanym sposobem dostępu do przeszłości. Emocjonalna bezpośredniość pamięci detronizuje powściągliwość historii i odzyskuje przeszłość jako źródło polityki tożsamości. Trzeźwy dystans historii jest nie tylko nudny, ale także rzuca wyzwanie naszemu posiadaniu przeszłości, którą pamięć pozwala nam wybierać. Przeszłość staje się tym, co Everyman chce zaakceptować, a nie tym, o czym mówią elity i eksperci. Preferencje osobiste pokonują obiektywną wiedzę [...] Ośmielony samolubnym solipsyzmem, dziś Everyman przykrawa przeszłość do własnego wyobrażenia, zaprzeczając różnicom i upodabniając ją do swoich uprzedzeń" (The Past Is a Foreign Country - 
3.

Z tego powodu, przy całej swej odwadze, książka Anny Nasiłowskiej jest w dobrym sensie tego słowa tradycyjna. Na przykład w porównaniu z takimi opracowaniami jak A New History of French Literature pod redakcją Denisa Holliera czy ANew History of German Literature pod redakcją Davida E. Wellbery'ego. Składają się one z kilkudziesięciu haseł ułożonych w porządku chronologicznym, które tworzą swego rodzaju mozaikę wydarzeń i dat ${ }^{19}$. Tymczasem narracja Nasiłowskiej, po pierwsze, przebiega wedle tradycyjnego podziału na epoki - choć tylko do zakończenia 2 wojny światowej. Od tego miejsca ulega poszatkowaniu na 5 osobnych części, są to w kolejności: Literatura polska po drugiej wojnie światowej, Poezja polska po 1956 roku, Wokót sceny i dramatu, Proza po 1956 roku, które funkcjonują na takich samych prawach jak, na przykład, części zatytułowane Romantyzm czy Pozytywizm. Ostatni rozdział Po roku 1980 jest raczej swego rodzaju konspektem niźli „regularną” całością. Ale nie ma wątpliwości, że był to świadomy wybór autorki.

Po drugie, raz jeszcze kwestia owego poszatkowania. Jest ona pochodną trudności, polegającej na tym, że „mamy w Polsce kłopot z ustaleniem, czym właściwie jest modernizm w polskiej literaturze, kiedy się zaczął i jak wyglądał" (s. 375). Co ciekawe, zdanie to Nasiłowska wypowiada w kontekście sporu o znaczenie roku 1905 (sporu zainicjowanego niegdyś, jak pamiętamy, przez Tomasza Burka). W innym miejscu Nasiłowska wyróżnia trzech najważniejszych poetów modernizmu - są to: Kasprowicz, Staff, Leśmian - zaznaczając, że „ich działalność wykracza poza okres przełomu XIX i XX wieku" (s. 340). Kiedy indziej za główną cechę powieści polskiej po roku 1956 uznaje "powrót do modernizmu" (s. 578). Zatem, a pogląd ten znamy, modernizm to nurt w ramach Młodej Polski (choć w odpowiednim rozdziale funkcjonuje nazwa „moderna” - s. 319 - która oznacza mniej więcej tyle, co

Revisited, Cambridge University Press, 2015, s. 596). Co ciekawe, Hoskins jest współredaktorem (z C. Happer oraz W. Merrinem) wydanego w tym roku tomu Trump's Media War (Palgrave Macmillan 2019), w którym Trump figuruje jako znak i beneficjent złamanej czy roztrzaskanej rzeczywistości, do czego zresztą doszło wcześniej, lecz dopiero teraz wyszło to na jaw. Nadchodzi faszyzująca rzeczywistość jak z Philippa K. Dicka.

19 A New History of French Literature, ed. Denis Hollier, Harvard University Press Cambridge, Massachusetts, London 1989, A New History of German Literature, editor-in-chief David E. Wellbery, Harvard University Press 2004. Hollier wyjaśnia: „Zestawienie wydarzeń ma na celu wytworzenie efektu heterogeniczności i zakłócenie tradycyjnego uporządkowania większości historii literatury: eseje poświęcone gatunkowi współistnieją z esejami poświęconymi jednej książce, instytucje są prezentowane obok ruchów literackich, duże przeglądy obok szczegółowych analiz konkretnych punktów orientacyjnych" (s. XIX). 
neoromantyzm). Jednocześnie pojawiają się pewne modyfikacje: Awangarda Krakowska "reprezentuje w Polsce dykcję wysokiego modernizmu” (s. 392), literatura okresu międzywojennego "sytuuje się w ramach europejskiego modernizmu" (s. 449), Rynek Kazimierza Brandysa (1968) znajduje się między „wysoką dykcją modernizmu a postmodernizmem” (s. 586). Być może mowa tu dwóch modernizmach, polskim i zachodnioeuropejskim (głównie anglosaskim), a autorka raz sytuuje opisywane zjawiska w kontekście polskim, innym razem europejskim - i stąd różnice w używaniu terminu. Niezależnie od tego, jasne pozostaje, że owo „poszatkowanie” śmiało idzie w poprzek scalających całą literaturę nowoczesną (poza tym - odmiennych) koncepcji modernizmu Ryszarda Nycza i Włodzimierza Boleckiego.

Po trzecie, akcenty i przesunięcia. W opisie renesansu Nasiłowska podkreśla wątki różnowiercze: kalwinizm Reja, sympatie protestanckie Kochanowskiego, „kacerską” działalność Jana Łaskiego, protestanckie koneksje Frycza Modrzewskiego, domniemaną konwersję Sępa (która ma, jak wiadomo, tłumaczyć jego żarliwość religijną). Sęp zresztą usytuowany jest obok Kochanowskiego - jako autor najwybitniejszy. W baroku Nasiłowska wyróżnia Jana Andrzeja Morsztyna i Paska („Pamiętniki Jana Chryzostoma Paska to wybitne dzieło”, s. 104). W oświeceniu prym wiodą Naruszewicz („Nie był ksiądz Naruszewicz wspaniałym poetą, ale jego zasługi są niewątpliwe", s. 125), Krasicki (postać najszerzej omówiona, obszerne streszczenie Mikołaja Doświadczyńskiego przypadków), Trembecki („poeta najdoskonalszy artystycznie", s. 138). W romantyzmie (i w całej książce) najwięcej miejsca zajmuje Mickiewicz, choć Nasiłowska nie ceni jego mesjanizmu, na Dziady każe spojrzeć oczami Boya (zob. s. 203), a o Panu Tadeuszu napisze m.in., że „przedstawia patriarchalny porządek jako naturalny i zmierzający do harmonii pod każdym względem” (s. 209). U Słowackiego wyróżni Grób Agamemnona, który „wraz z liryką obywatelską Kochanowskiego stanowi tradycję dla polskiej poezji obywatelskiej XX wieku" (s. 226); o Kordianie napisze, że jego przesłanie brzmi „poświęcenie - tak, ale świeckie, bez sakralizacji” (s. 228); o Królu-Duchu z przekąsem powie, że „stanowi nie lada wyzwanie interpretacyjne dla racjonalnej świadomości” (s. 242). Fredro "nie był romantykiem” (s. 255). Norwid opisany jest w rozdziale o pozytywizmie, który rozpoczyna się od prezentacji Kraszewskiego - zostaje on wysoko wyniesiony. Nasiłowska pisze o Kraszewskim dużo więcej i pochlebniej niż o Norwidzie. Najwyżej ceni Prusa, ale m.in. za to, że „w Lalce wskazywał poezję romantyczną jako jedną z przyczyn polskich nieszczęść" (s. 295). O Trylogii Sienkiewicza czytamy, że choć jest „krytykowana za uproszczenia historyczne”, to „przynosi jednak obraz dawnej 
Rzeczpospolitej jako skomplikowanej mieszanki języków i kultur" (s. 305). W prezentacji Młodej Polski zwraca uwagę, że została w niej omówiona cała twórczość Leśmiana, choć to poeta „osobny” (s. 345), i że na samym początku podrozdziału o Żeromskim zostaje aprobatywnie przywołana opinia Cata-Mackiewicza, iż pisarz ten „rozhisteryzował naród” (s. 349). W okresie międzywojnia jako nurt główny zostaje wyróżniony Skamander, co jest - jak się zdaje - nie tylko stwierdzeniem, ale też i potwierdzeniem historycznego faktu; tym bardziej, że dalej Nasiłowska wraca do tematu, omawiając jeszcze powojenne Przemiany skamandrytów (s. 533-539). Osobny podrozdział poświęca Skamandrytkom (s. 406-409). Zwraca uwagę sceptycyzm wobec Miłosza, więcej nawet - ani on, ani Różewicz i Herbert nie przytłaczają (ani razem, ani któryś z osobna) krajobrazu literatury po 1945 roku. Podobnie Szymborska. Analogicznie dzieje się z Gombrowiczem - to Andrzejewski i Miłosz nazwani są "dwoma najlepiej zapowiadającymi się młodymi twórcami lat trzydziestych" (s. 463). Oczywiście, dokonana tu enumeracja jest bardzo wybiórcza - ale nie może być inaczej.

Po czwarte, przez całą książkę rozwija się wątek obecności kobiet, czasem przybierający formę opowieści o obecności erotyzmu w polskiej mentalności. W ten sposób wątek ten się rozpoczyna - od opowieści Ibrahima Ibn Jakuba, „że [jeśli] po ślubie mąż odkrywał, że żona jest dziewica, miał prawo ją oddalić, uznając, że skoro nikt wcześniej nie znalazł w niej niczego pociągającego, widać nie była wiele warta" (s. 20). Dalej przeczytamy m.in. o szukaniu żony u Reja (s. 51), mizoginii Frycza-Modrzewskiego (s. 68, 70), erotykach Sępa (s. 80), kobiecie w baroku oraz królowej Marysieńce (s. 97-100), sypianiu z nagą żoną u Paska (s. 107), pierwszej polskiej dramatopisarce Urszuli Radziwiłłowej (s. 109), wierszu Trembeckiego o utracie cnoty (s.139), o tym, kim jest Matka Polka - przy okazji wiersza Mickiewicza (s. 196), o epoce kobiet w literaturze, w kontekście szkicu Świętochowskiego (s. 284), o Konopnickiej i Marii Dulębiance (s. 288), wzorach kobiecości pod koniec XIX wieku (s. 298), określeniu „sztandar ze spódnicy” (s. 312), transseksualizmie Komornickiej (s. 318), Nałkowskiej wypowiedzi o „tzw. «kobietach uczciwych»" (s.418), szkicu Boya Literatura mniejszości seksualnych („pionierski choć powierzchowny”), s.426). Wyliczenie jest długie (mogłoby być dłuższe), ma bowiem pokazać, w jaki sposób Nasiłowska zarazem bawi i edukuje czytelnika.

Po piąte, przez niemal całą opowieść Nasiłowskiej przebiega linia narracyjna mówiąca o Żydach. Zaczyna się od stwierdzenia, że „historia Żydów w Polsce liczy tysiąc lat" (s. 43). Dalej Nasiłowska m.in. zwraca uwagę na 
powieść Lejbe i Siora Niemcewicza (s. 159), przedstawia osobny podrozdział Asymilacja Żydów w powieści Kraszewskiego (s. 273-275), zajmuje się obecnością Żydów w pismach Orzeszkowej (s. 282-283), daje glosę (obok toku głównego Nasiłowska daje kilkadziesiąt glos) o Postawach żydowskich: między asymilacja a syjonizmem (s. 427-428). Znacząca jest też inna glosa o tytule Przerwana tradycja, poświęcona Stryjkowskiemu jako „największemu z pisarzy polskich podejmujących temat kultury żydowskiej”, s. 593).

Po szóste, linia ukazująca filiacje obce polskiej literatury. Znajdziemy tu uwagi poniekąd spodziewane, np. glosę o Janie Potockim (s. 160-163), ale też m.in. krótki ekskurs o Staszicu u Dickensa (s. 157), informację o tym, że Poloniusz w Hamlecie swe imię zawdzięcza Goślickiemu (s. 72), glosę o karierze literackiej Mazepy i Beniowskiego (s. 175, 234). Tę znów - dłuższą niż wynika z liczby przytoczeń - linię narracyjną w sporej części wypełniają wstawki erudycyjne. Są one cenne i dodają smaku całości.

Po siódme - pytanie, czego Nasiłowska najbardziej nie lubi? Tradycji kontrreformacji i mesjanizmu, czy to w wersji w sarmackiej czy romantycznej. Na przykład, z jawną goryczą pisze o Skardze: „Jako duchowny głosił kazania o treściach politycznych - nie był tu pierwszy, ale to on stał się symbolem idei, że Polska powinna być katolicka, a wiara jest gwarancją jedności, cnoty i boskiej opieki. Jednocześnie - jego wymowa, retoryka, sztuka krasomówcza, sposób argumentacji robiły na słuchaczach wielkie wrażenie. Po utracie przez Polskę niepodległości pamiętano o Skardze jako niemalże proroku [...] Obrazowy styl i dobra polszczyzna sprawiły, że [jego] dzieło [żywoty i kazania] było w użytku przeszło trzysta lat, przyczyniając się do utrwalenia archaicznych cech dewocji katolickiej" (s. 86).

Obecność wymienionych 7 wątków decyduje o oryginalności przedsięwzięcia Anny Nasiłowskiej. Choć oczywiście liczą się nie tylko one, ale też wcześniej przedstawione założenia teoretyczne oraz kontekst prac innych historyków literatury.

\section{4 .}

Nie tylko historie literatury odpowiadają na nasze wyobrażenia na temat przeszłości i przyszłości, ale także - i to w jeszcze większym stopniu - nasze sądy na temat tego, czym historia literatury być powinna lub być mogła.

W 1992 roku David Perkins zastanawiał się, czy historia literatury jest możliwa? Z jego książki zapamiętaliśmy głównie to pytanie, tymczasem równie ważna była kwestia, czy historia literatury jest konieczna - i z jakich 
powodów? ${ }^{20}$ Jedna z odpowiedzi brzmiała: „bo nie chcemy być więźniami teraźniejszości"21. Odpowiedź ta nie straciła wagi, a książka Anny Nasiłowskiej skutecznie pokazuje, że istnieją różne modele polskiej tożsamości. W naszej dzisiejszej sytuacji jest to zaleta nie do przecenienia.

Jeszcze dawniej, bo w roku 1974, Stefan Sawicki zauważył, że „Łatwo było krytykom I połowy XIX w. podejmować śmiałe syntezy, gdy nie było jeszcze myśli metodologicznej; nie byli oni po prostu świadomi trudności, które niesie ze sobą ich praca, a nieświadomość bywa - jak wiadomo - sprawczynią dokonań monumentalnych. Dziś wymagania metodologiczne są tak duże, że paraliżują często śmielsze zamysły"22. Od tamtego czasu świadomość metodologiczna postąpiła bardzo daleko naprzód - tak daleko, że niekiedy wydaje się, iż najrozsądniej byłoby przejść ponad nią, aby gdziekolwiek dojść. Anna Nasiłowska wykonuje tego rodzaju gest: świadoma wszelkich komplikacji zachowuje wobec teorii dużą suwerenność, nie wpisując się ostatecznie w żadną szkołę teoretycznoliteracką (nie rezygnując zarazem z własnych sympatii i preferencji).

Zmiana, która zaszła od czasów artykułu Sawickiego polega też - jak się zdaje - na tym, że dziś mamy dużo więcej wątpliwości na temat tego, co jest śmiałe, a co asekuracyjne. W czasach, gdy liczy się nade wszystko śmiałość, dokonaniem najśmielszym może okazać się brak uporczywej śmiałości. Wspominam o tym, gdyż Historia literatury polskiej Anny Nasiłowskiej wydaje się dziełem nadzwyczaj udanie zbalansowanym: wyciąga wnioski z dokonujących się w kulturze zmian, lecz im się nie poddaje; jest nowatorska, ale zachowuje silne związki z tradycją i ostatecznie tradycję podtrzymuje; stanowi dokonanie autorskie, a zarazem dzięki swemu zdyscyplinowaniu przekazuje wiarygodny i spójny obraz przeszłości. Ostatecznie - mocno odróżnia „wartości trwałe”, od tych, „które należało i należy w narodzie tępić”. I bardzo dobrze.

D. Perkins Is Literary History Possible?, The Johns Hopkins University Press 1992, s. 17. wińskiego, Zakład Narodowy im. Ossolińskich, Wrocław-Warszawa 1974, s. 204. 


\section{Abstract}

\section{Andrzej Skrendo}

UNIVERSITY OF SZCZECIN

A History of Polish Literature for the Twenty-First Century

Skrendo discusses Anna Nasiłowska's Historia literatury polskiej [A History of Polish Literature, Warsaw 2019] in a broad comparative context: existing twentieth-century syntheses of the history of Polish literature, the methodological problems of literary history, contemporary memory studies. Social and cultural changes related to the spread of new media form the broadest context.

\section{Keywords}

literary history, memory studies, new media 